\title{
PRESS RELEASE
}

\section{The Revision of the 2012 Groatian central government budget: unrealistic planning of the budget and/or incapacity to implement what has been planned}

\author{
KATARINA OTT, PHD, Institute of Public Finance, Zagreb
}

\begin{abstract}
It was on the very date that according to the Budget Law it was supposed to define and send to the Parliament the Budget Proposal for 2013-2015, November 15, that the Government actually presented its Proposal for Amendments to the State Budget of the Republic of Groatia for $2012^{\mathrm{I}}$ (i.e. a revision of the budget).
\end{abstract}

Since this Proposal was announced just a few days before, the Government left the public, and itself, no time to analyse the revision or to draw the essential conclusions that could be factored into the planning of budgets for the forthcoming years. This is just a continuation of the practice of belatedness practised to date ${ }^{2}$ for the Strategies of the Government's Programmes were two months late, and the Guidelines for Economic and Fiscal Policy a month and a half. But the budget calendar is laid down by the Budget Law precisely so that there should be enough time for analysis, debate and the adoption of the best choices for the future fiscal policy of the state.

No date for the publication of revisions of the Budget is given, because they only ever arrive if during the course of the budgetary year it is established that budgetary revenues have been estimated unrealistically or if unforeseen expenditures have arisen. They can be caused by unforeseen circumstances in the local or world economy, but can also be the consequence of the Government's incapacity realistically to plan revenues and expenditures. Although revisions should occur only in extraordinary circumstances (for example, Ireland, in the 1996-20Io period, had only one revision of the budget, and that was in the crisis year of 2009), but in Croatia they are a regular phenomenon, and previous governments had budgetary revisions as many as I4 times in a period of II years. ${ }^{3}$

Since this revision has not been brought about by a shortfall in revenues but by exceeding the planned expenditure, this article will deal exclusively with the increases in expenditures displayed.

Government revenues consist of operating expenditures and expenditures for the acquisition of nonfinancial assets. In the Revision, operating expenditures have been enlarged by I.9 billion kuna (I.I billion for employees, 458.3 million for payments to individuals and households, 4I5.8 million for financial

\footnotetext{
${ }^{\mathrm{I}}$ Government of RC., 2012. Draft Proposal for Amendments to the Government Budget of the Republic of Croatia for 20I2. $6 \mathrm{I}^{\mathrm{st}}$ session of the Government, November 15, 2012.

2 Ott, K. 2012. "Overview of the Guidelines of Economic and Fiscal Policy for the period 2013-2015". Press Releases, No. 40, September 3, 20I2. Zagreb, Institute of Public Finance.

${ }^{3}$ Beš, D. and Ott, K., 20I2. "A short history of revisions of the Croatian government budget 1999-2009”. Newsletter, No. 50, August 20Io. Zagreb, Institute of Public Finance.
} 
expenditures, and 379.78 million for subsidies). ${ }^{4}$ Expenditures for the acquisition of non-financial assets were reduced by 424 million. What is demonstrated by the differences between the amounts planned at the end of February and those shown now in November, in a period of less than nine months?

We shall leave the greatest increase in expenditures - for employees - until the end, and set off from expenditures for the acquisition of non-financial assets, which were considerably reduced. Although fiscal consolidation implies reduction of expenditure, it is not good if it is above all of expenditure for the acquisition of non-financial assets that is cut. This means that the investment projects upon which the Government founds its plan for recovery are simply not being implemented. The explanation according to which "not even a single investment project is being relinquished, rather, for some of the planned projects the preparation of the tender documentation is taking a bit longer", indicates unrealistic planning of the time needed for the preparation of projects, and accordingly unrealistic initial planning of the budget.

Subsidies to public sector companies were reduced negligibly (less than I\%), but as if to compensate they were considerably increased to corporates, farmers and self-employed outside the public sector. Almost $60 \%$ of this increase relates to shipbuilding, about 30\% to incentivising farm production and market interventions and the rest, for example, to the active employment policy, the processing industry, tourism, traditional artisan crafts, education for enterprise and self-employed persons, women's entrepreneurship. Most of the enlargement is explained by aid "in the Split shipyard restructuring procedure in line with the Draft contract on the sale and transfer of shares of Split shipbuilding industry and DIV shipbuilding". But even if we ignore the level of realism implicit in this kind of sale and how remunerative it is, because of the inadequate information about the negotiation procedures the question arises of whether this is not just another indicator of unrealistic planning capacity of the Government for the handling of such major undertakings and accordingly for the planning of the budget? The shipbuilding story, unfortunately, is not over; it will cost us a lot in future budgets, and it is to be hoped that the entry of Croatia into the EU will lead to an outcome, and that shipbuilding, at least in the future, will not be one of the main causes of budget revisions.

Financial expenditures relate to "interest that is rising primarily because of the half-yearly payment of interest on bonds issued this year and obligations for the loans to shipyards that have been assumed". Since the Government assumed the liabilities of the shipyards in April ${ }^{5}$ and took the decision to issue bonds in the first half of the year ${ }^{6}$, how is it that it did not notice earlier on the inevitability of these additional expenditures?

The rise in payments to individuals and households is primarily caused by an increase in expenditures for employees in healthcare establishments (by as much as 510.4 million kuna). But why are these expenditures (and which establishments and which employees are concerned?) placed among payments to individuals and households pursuant to insurance and other payments, and not in expenditure for employees (position 37 instead of 3I)? If these two amounts were shown in the same place, expenditure for employees would have risen by I.6 billion and not I.I billion. Why is a distorted picture of the real purpose of individual expenditures being created? ${ }^{7}$

Expenditures for employees consist of gross wages, other expenditures for employees and employers' contributions. Since gross pay determines employers' contributions, and quite a lot of other expenditures for employees, and since expenditures for gross wages contributed most to the rise in total expenditures of the government budget (837.5 million kuna expenditure for gross pay amounts to $86 \%$ of expenditures for employees and $44 \%$ of overall operating expenditures), it is worth looking at them in greater detail.

\footnotetext{
${ }^{4}$ The aggregate of all increased operating expenditure is greater than the total enlargement of these expenditures, because at the same time material expenditures, aid given to other countries and within the general budget, and other expenditures, were reduced by 450 million kuna.

${ }^{5}$ Government Republic of Croatia, News and announcements. The Government assumed the credit liabilities of 3 maj, Brodotrogir and Brodosplit, April 5, 2012.

${ }^{6}$ Government Republic of Croatia, Conference call session of the Government Republic of Croatia, April 25, 2012

${ }^{7}$ Bronić, M., 2012. "Revision of the government budget for 2012: why are the expenditures of the government budget rising?". Press Releases, No. 43, November 19, 2OI2. Zagreb: Institute of Public Finance.
} 


\section{Graph: Increase in expenditures for gross wages of employees in the Revision of the Budget for 2012, in millions of kuna*}

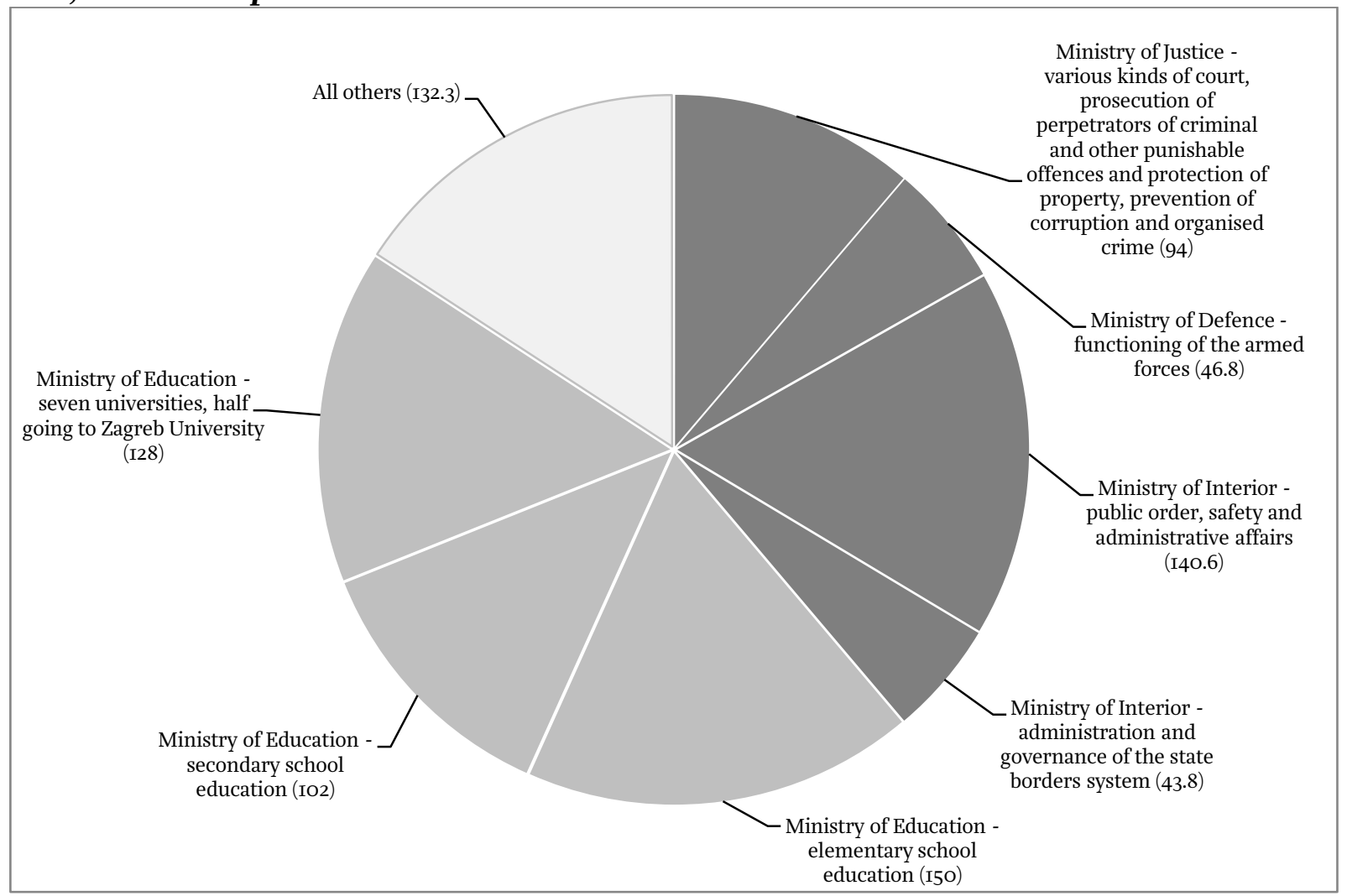

Source: Government of the Republic of Croatia

* only budget position $3 \mathrm{II}$

It is easy to conclude that over $45 \%$ of the growth in expenditures for gross wages relates to education (primary, secondary and tertiary), and almost $40 \%$ to various forms of security and protection (above all, the police). The remaining $15 \%$ relates primarily to the Croatian Institute for Health Insurance, the Ministry of Agriculture, the government administrative offices in the counties, the Employment Agency and the Croatian Retirement Insurance Institute, but many much smaller beneficiaries also take part (for example, the Croatian National Theatre in Zagreb increased its wage bill by 2.3 million kuna). Once again it is worth pointing out that the graph refers only to the 837.5 million kuna rise in expenditures for gross wages of employees (position 3II) and excludes expenditures for health care employees, which are entered under payments to individuals and households pursuant to insurance and other payments (position 37). A proper recording of all items in the budget, including these, would give a different picture; but that is not possible to read from this documents.

Since in nine months - the time that elapsed from the adoption of this year's budget to its being revised - there were no unforeseen circumstances in either the local or the world economy, why did the Government plan its revenues and expenditures so unrealistically? Unreal planning of revenues and expenditures led inevitably to considerable differences in the financing account. Apart from that, the government will this year not be able to realise the 2 billion kuna receipts from the sale of stocks and shares in the principal of credit and other financial institutions in the public sector. Although there is no explanation for this failure in planning, it can be assumed that it concerns the planned but not effectuated sales of Croatia Insurance Company and the Croatian Postal Bank. But then, by issuing bonds, the government took on as much as 3.7 billion more debt than had been planned.

\footnotetext{
${ }^{8}$ It is worth pointing out for the umpteenth time that coping with the budgetary documents would be considerably facilitated if they were released on the Government's Web site in excel and not in pdf. Since the Finance Ministry certainly produces them in excel, is the Government just providing them to the citizens in pdf, or is it getting them itself in this form?
} 
It is a huge pity that because of the unrealistic planning of the budget and/or incapacity to implement what has been planned, yet another year has been lost. And this was the first year in office, which is considered for every government the most favourable for implementation of any kind of measures, particularly of the unpleasant kind. In this way, alas, too little has been done significantly to repair public finances. 